\title{
Foreign Exchange Reserves and India's Import Demand: A Cointegration and Vector Error Correction Analysis
}

\author{
Zafar Ahmad Sultan (Assistant Professor) \\ College of Business Administration, Al Kharj University \\ P.O. Box 165, Al-Kharj 11942, Kingdom of Saudi Arabia \\ Tel: 966-590-712-229Ｅ-mail: zsultan.sultan@gmail.com
}

Received: January 4, 2011 Accepted: February 10, 2011 doi:10.5539/ijbm.v6n7p69

\begin{abstract}
The paper investigates the aggregate import demand function for India using Johansen's cointegration method. The result shows that there is a long run equilibrium relationship between real imports, real income, relative price of imports and real foreign exchange reserves. In the long run, import is found to be elastic with respect to income, and inelastic with respect to relative price and foreign reserves. In the short run also, we find a significant relationship between import, income, relative price and foreign exchange reserves. However in the short run, import is found to be inelastic with respect to all of these variables. The evidence suggests that depreciation may not give desirable results for the economy as far as containing the import bill is concerned. The promotion of export would be a better option to take care of problem of trade deficits.
\end{abstract}

Keywords: Import, GDP, Relative price of imports, Foreign exchange reserves, Cointegration

\section{Introduction}

Foreign exchange (F.E.) reserves is considered as an important determinant of import demand, more so, of developing countries. Since this is the only medium of exchange in international market, it acts as a constraint for the developing countries to import necessary goods and services. Thus, any increase in the foreign reserves may be expected to accompany an increase in import of goods and services. This is the hypothesis which this paper intends to examine in the case of India. Many a times India experienced an adverse effect on its pace of economic growth for want of necessary inputs due to inadequate foreign exchange reserves. More recently, in 1991 when F.E. reserves plummeted to just fifteen days of imports, India faced severe economic crisis for non availability of important inputs required for sustaining growth. Since the inception of economic reforms in 1991, the reserves of foreign exchange have increased to a comfortable level. During the period import has also increased at a high rate of over 25 percent per annum. It is in this context, the paper seeks to examine the import demand function for India and its relation with F.E. reserves, both in the long run and in the short run.

The rest of the paper is organized as follows. Next section briefly presents the review of literature. This is followed by model specification and methodology. Empirical result is presented in section IV. Final part concludes the paper.

\section{Review of Literature}

Many researchers have carried out studies on behavior of import demand of the developing countries and related import to relative price of imports and income of the country (Dutta and Ahmad, 1997; Sinha, 1997; Cheong, 2003; Chang and Juang, 2005; Kalyoncu, 2006). Most of these studies found a negative relation of import with its price and negative relation with income of the country. In addition to income and relative price of import, Dutta and Ahmad (2006) also used dummy variable to incorporate the effect of trade liberalization on imports, while examining India's import function. He concluded that the income and price has positive and negative influence respectively on import demand while liberalization has not significantly affected India's import.

In addition to above studies, there are number of studies which have included foreign exchange reserves as an important determinant of import demand. Zelal Kotan and M. Saygili (1999) in their paper estimated the import demand function for Turkey for the period of 1987 to 1999. Using quarterly data they incorporated two different models- Engle-Granger approach and Bernanke-Sims structural VAR model. The result of the Engle-Granger approach shows that in the long run, import is significantly related to income, nominal depreciation rate, inflation and international reserves. Further, import has been found to be income and price elastic. The Bernanke-Sims structural VAR model shows that the anticipated change in real depreciation rate and unanticipated change in income and real depreciation rate have significant effect on import. Moran (1989) included foreign exchange receipt and international reserves, in addition to relative price of import and income of the country, in his model and found significant coefficient for these variables in the case of developing countries. Arize et al (2004) found cointegration relationship between real import, relative price of imports, 
income and foreign exchange reserves. A.K. Dash (2005) however used a different model to estimate the determinants of import. Instead of using relative price of import, he used import price and domestic price as separate factors to estimate the impact on import demand separately. He also used foreign exchange reserves as an important determinant of the import demand. He concluded that the import has long run relation with GDP, import price, price of domestically produced goods and foreign exchange reserves. However, the import is found to be more sensitive to the price of domestically produced goods than the other factors. Arize and Osang (2007) found similar result in the case of seven Latin American Countries. Further, he found that the elasticity of import is greater than one with respect to income, close to one with respect to import price, and small with respect to foreign reserves.

\section{Model Specification and Methodology}

Most of the econometric investigations of import demand function postulate that import is function of real income of the country and relative price of import (Houthakker and Magee, 1969; Leamer and Stern, 1970; Murray and Ginmen, 1976; Goldstein and Khan, 1976; Carone, 1996). However, in order to examine the import demand function for India, foreign exchange reserves has also been included in the model. The reason for including foreign reserve in the model is that this is the only medium of exchange in international market and acts as a constraint for the developing countries like India to import necessary inputs. The desired level of import cannot be actualized in the absence of sufficient level of F.E reserves. Thus, omitting this important variable, while examining the import demand function for India, may result in bias of a model's estimate and overstate the importance of the included variables. This is the reason the F.E. reserves has also been included in model to examine whether the reserves is also an important determinant of demand for import in the case of India. One may expect a rise in demand for imports with increase in foreign reserves and vice-versa. Following Marshallian theory of demand, this model assumes homogeneous of degree zero with respect to GDP, import price and foreign reserves, implying absence of money illusion. With this background the import demand model of India for $t$ period can be specified as

$$
\mathrm{M}_{\mathrm{t}}=\mathrm{f}\left(\mathrm{GDP}_{\mathrm{t}}, \mathrm{RP}_{\mathrm{t}}, \mathrm{FE}_{\mathrm{t}}\right)
$$

Where,

$\mathrm{M}_{\mathrm{t}}$ is Real import.

$\mathrm{GDP}_{\mathrm{t}}$ is real income of the country.

$R P_{t}$ refers to relative price of import.

$\mathrm{FE}_{\mathrm{t}}$ refers to real foreign exchange reserves.

$\mathrm{T}$ refers to time period $\mathrm{t}$.

For estimation purpose, the choice between linear and log linear model is important because the functional form affects the explanatory power of the variables. Kmenta (1986) argued that the misspecification of functional form may result in misspecification of error term, that in turn results in violation of assumption of OLS and hence efficiency and biasness of the parameter. Though there are different test for the selection of appropriate model (Box and Cox, 1964; Sargan, 1964; Bera and McAleer, 1989); Khan and Ross (1977), Boylan et al (1980), and Doroodian (1994) are of the view that the log linear model should be preferred over linear model because of certain advantages associated with it. It allows the researcher to interpret the coefficients of the dependent variables directly as elasticity with respect to the independent variables. It is also useful for accommodating the hetroskedasticity problem (Goldstein and Khan, 1976). Besides, Gafar (1988) argued that log linear form also takes care of the problem of multicollinearity. Thus, for the present study, log linear model is selected to examine the import demand function for India.

Since India imports only small proportion of total world export, it may not be unrealistic to assume that the world supply of export to India is perfectly elastic. The implication of this assumption is that the world may change the supply of export to India even without changing its price. With this assumption, our model reduces to single equation model i.e. estimation of mere import demand function. The long run import demand model can be expressed in following way,

$$
\mathrm{LM}_{\mathrm{t}}=\beta_{0}+\beta_{1} \mathrm{LGDP}_{\mathrm{t}}+\beta_{2} \mathrm{LRP}_{\mathrm{t}}+\beta_{3} \mathrm{LFE}_{\mathrm{t}}+v_{\mathrm{t}}
$$

Where $v_{\mathrm{t}}$ is white noise error term and is normally distributed. $\mathrm{L}$ indicates the natural logarithm of the respective variables.

The theory of demand says that there is negative relationship between price and its quantity demanded assuming other things constant. As the price of imports in relation to the price of domestic substitutes increases, we may expect decrease in its demand, and vice versa. The increase in income (GDP) of the country would cause increase in aggregate demand and so of imports also. However, the relationship between the demand for import and GDP also depends upon the source of increase in GDP. If GDP increases due to increase in production of import substitute goods, then import will have negative relation with the GDP. Foreign exchange reserves enable a country to make its demand effective. For, in absence of foreign reserves a country cannot make payment for imports whatsoever be the level of income and price. Thus, higher the reserves, the country would have more 
capacity to import, and one may expect a country to import more and vice versa. On the basis of these propositions we expect negative sign for $\beta_{2}$, and positive sign for $\beta_{3}$. $\beta_{1}$ may take either positive or negative sign depending on the sources of growth of GDP i.e. $\beta_{1}>0$ or $\beta_{1}<0 ; \beta_{2}<0$; and $\beta_{3}>0$.

The study covers the period from 1970 to 2008. To estimate the model we use annual data for the period under study. The data on unit value index of import, amount of import and GDP and foreign exchange reserves have been taken from UNCTAD (2009). The data on wholesale price index is taken from International Financial Statistics published by IMF.

Since the data used in the present study are time series data, the study begins the analysis by examining the time series properties of the data. If the variables are stationary (mean and variance of the variables remain constant over a period of time), ordinary least square (OLS) method can be applied to estimate the relationship among the variables. However, if the variables are found to be non stationary at level (i.e. mean and variance of the variables are time variant), application of OLS method may give spurious result (Granger and Newbold, 1974). To make the data stationary, we take the first difference of the data, and then estimate the equation. But this method removes the long run behavior of the data as the result captures only short run relationship between the variables. In such cases, to examine the presence of long run relationship between the variables, cointegration and error correction model is considered to be the better method. When the variables are non stationary at level but are integrated of the same order, there can still be long run relationship between them if they are co-integrated. The variables are said to be co-integrated if a linear combination of these variables are stationary. When the variables are co-integrated we can say that there exists a long run stable relationship between the variables meaning thereby stochastic trends in real import is related to stochastic trend in real income, relative price of import and real foreign exchange reserve. Any deviation from the equilibrium will get automatically corrected and the variable will revert back to its equilibrium level. Once the cointegration among the variables is established, error correction model (ECM) is estimated to examine the short run dynamics of the relationship.

In the present study, in order to test the order of integration, augmented Dicky-Fuller (ADF) test and Philips-Perron (PP) test is applied. To test the presence of cointegration, Johansen approach (1988) approach has been applied. This method is superior to Engle-Granger two step approach (1987) for following reasons. One, in the case of Engle-Granger approach estimation of long run equilibrium relation requires regressing one variable on rest of the variables. But, in practice, sometimes we find that one regression equation shows existence of cointegration, while reversing the order of the variables alters the result altogether and shows no cointegration. This is an undesirable feature of cointegration procedure as presence or absence of cointegration should be independent of the order of the variables presented on the left hand side or the right hand side of the equation. On the other hand, Johansen method does not rely on any arbitrary normalization. Two, in the case of more than two variables, there is possibility of more than one cointegrating relationship between the variables. However, Engle- Granger method does not detect more than one cointegration relation. Johansen method allows for tracing more than one cointegrating vector in the data by calculating maximum likelihood estimates. Third, Engle-Granger approach relies on two step estimator. The first step is to generate error series and second step is to estimate a regression for this series in order to see if the series is stationary or not. Hence, any error introduced in first step is carried into the second step. Finally, Johansen's procedure allows for testing certain restrictions put on the variables by the economic theory, like, sign and size of the elasticity estimates.

In this method, the number of cointegrating relations is tested on the basis of trace statistics and maximum Eigen statistics. Once presence of cointegration is established, we estimate an error correction model (ECM) that includes both long run and short run information.

$$
\Delta M_{t}=\alpha_{0}+\delta E C T_{t-1}+\sum_{i=1}^{n} \alpha_{1 i} \Delta M_{t-i}+\sum_{i=1}^{n} \alpha_{2 i} \Delta G D P_{t-i}+\sum_{i=1}^{n} \alpha_{3 i} \Delta R P_{t-i}+\sum_{i=1}^{n} \alpha_{4 i} \Delta F E_{t-i}+\varepsilon_{t}-
$$

Error correction model consists of two types of components. One, error correction term with one period lag $\left(\mathrm{ECT}_{\mathrm{t}-1}\right)$. The coefficient of error correction term $(\delta)$ is feedback effect or the adjustment effect. This measures the speed of adjustment to long run equilibrium condition i.e. to the extent the disequilibrium created in previous period is corrected in period t. There are as many error correction terms as are the number of cointegrating vectors. Two, the first difference lagged regressors, the coefficients of which $(\alpha 2 \mathrm{i}, \alpha 3 \mathrm{i}, \alpha 4 \mathrm{i})$ are impact multiplier (short run effect) that measure the immediate impact that a change in regressors will have on the dependent variable. $\varepsilon_{\mathrm{t}}$ is white noise error term.

The VEC Granger causality / block exogeneity Wald test is then conducted to find the short run causal relation of import with the explanatory variables through joint significance of each of the first differenced lagged explanatory variables.

\section{Empirical Analysis}

Since the application of cointegration requires that all the variables should be integrated of the same order, we start the analysis by examining the unit root properties of the variables. The result is shown in table $1 \mathrm{a}$ and $1 \mathrm{~b}$. The result of both the methods (ADF test and PP test) shows all the variables are non stationary at level but are 
stationary at first difference. This implies that all the variables are integrated of order one i.e. I (1). Thus we can apply Johansen cointegration approach to examine the long run relationship of import with income of the country (GDP), relative price of import and foreign exchange reserves.

The result of cointegration and error correction model is significantly affected by the lag length of the variables. Therefore, determination of appropriate lag length is an important prerequisite of cointegration and VAR analysis. Since the present study is using annual data, a maximum of three period lag, as a rule of thumb (Charemza and Deadman, 1992), is taken to find the appropriate lag length. On the basis of Akaike Information criteria (AIC), Hannan-Quinn information criteria (HQ), final prediction error (FPE), and sequential modified LR criteria, a lag of two period is selected (see table 2).

The present study has selected model 2 (intercept and no trend in CE and no intercept and no trend in ECM) of the five alternative models to examine the long run relationship among the variables. The cointegration results are given in table $3 \mathrm{a}$ and $3 \mathrm{~b}$. The tables show that the trace statistics and maximum Eigen values are greater than the critical values at 5 percent significance level. Hence we reject the null hypothesis that there is no cointegration relationship between these variables. The trace statistics and the Eigen statistics for at most one cointegration $(r \leq 1)$, however, is less than the critical value. Thus we cannot reject the null hypothesis and conclude that there is one cointegrating vector among four variables included in the model. In other words, there is unique equilibrium relationship among import, relative price of import, GDP and foreign exchange reserve. The long run relationship can be expressed in following form:

$\mathrm{LMt}=-14.49-0.29 \mathrm{LRPt}+1.88 \mathrm{LGDPt}+0.21 \mathrm{LFEt}$

S.E. $\quad(3.00) \quad(0.14)$

t-values [4.83] [2.07]

The result shows that import has long run relation with all these variables. The import is negatively related to relative price of import and has positive relation with income of the country and the foreign exchange reserves. Thus, the result provides strong support for the theoretical prediction about the impact of income, foreign exchange reserves and the relative prices on import of the country. As far as the relative strength of the variables in influencing the import is concerned, income showing economic activity of the country comes out to be the most influential determinant of import with elasticity as high as 1.88 , followed by relative price elasticity with -0.29 and then by foreign exchange reserve with 0.21 elasticity. This is also expected as about 70 percent of import is comprised of intermediate and capital goods. When economy grows, more of such goods are required to facilitate the growing needs of the economy and change in the price level does not affect its demand level to a large extent.

\subsection{Estimation of Error Correction Model (Short Run Dynamics)}

The result of ECM is given in table no. 5. The model seems to be good in the sense that it satisfies the diagnostic test and also has a high $\mathrm{AR}^{2}$ value of 0.78 . The result of the diagnostic test shows that there is no serious problem of serial correlation and hetroskedasticity. The error term is also found to be normally distributed. The coefficient of error correction term with one period lag is negative and significant signifying that above long run relationship is stable and any disequilibrium created in the short run will be temporary and will get corrected over a period of time. The magnitude of coefficient shows that import will adjust about 40 percent of its total deviation from long run equilibrium level in one time period i.e. in a year. That means it will take two and a half years for import to reach its long run equilibrium path if any disturbance is created in the short run. Further, in short run, coefficients of all the variables have expected sign and are significant. However, as compared to the long run coefficients, the short run coefficients are smaller for all the variables. The import turns out to be income inelastic in the short run while it was elastic in the long run. The result of VEC Granger causality / block exogeneity Wald test, given in table-6, reveals that all the three variables have causal relation with import.

\section{Conclusions and Policy Implications}

Over the past few years, India's import has increased at a rapid rate. The period has also witnessed a high rate of growth of the economy and comfortable level of foreign exchange reserves. In the light of this, the paper intended to examine the determinants of India's merchandise import, both in long run and in the short run, applying Johansen's cointegration and vector error correction method. To examine the demand function for imports, foreign exchange reserves, in addition to income and relative prices of import, has also been included in the model to estimate its importance in determining the import volume. The main results of the study can be summarized as follows.

The cointegration result shows that there is long run equilibrium relationship between India's real import, real income, relative price of import and the foreign exchange reserves signifying the relevance of including foreign exchange reserves in the model. Analyzing the size of the coefficients, we find that the domestic income turns out to be the most important factor determining the volume of import in the long run as well as in the short run. The empirical estimate shows that long run import is elastic with respect to income and inelastic with respect to relative price of import and foreign reserves. This implies that the import volume would grow at faster rate than 
the growth in income of the country and would deteriorate the trade balance of the country if the growth in income is not accompanied by growth in exports.

Foreign exchange reserves turns out to be statistically significant factor affecting import demand both in the short run as well as in the long run. However its economic impact is relatively small in particular to the size of estimated income elasticity but close to price elasticity. Nevertheless, it constitutes an important determinant of import, and omitting such an important variable may cause misspecification of the model and may lead to overemphasizing the influence of the variables included in the model.

With respect to price also, India's import is found to be significantly related to, both in the long run and in the short run. However, the low coefficient implies that India's import is non competitive in nature and import substitution industrialization (ISI) strategy has not been able to successfully provide the domestic substitutes to these products to compete with these imports. Since the price elasticity is very low and even less than the range of -0.5 to -1.0 as suggested by Heien (1968), even depreciation may not be an effective policy to reduce the trade deficits. This is also evident from the fact that despite the continuous depreciation of the rupee since the reform period, the trade deficits continues to rise. Recognizing the nature of imports, controlling import without providing adequate domestic substitutes may not be desirable as it may have an adverse impact on the growth of economy. Hence promoting export through appropriate measures would be the better remedy to take care of the problem of trade deficits in future.

\section{References}

Arize, A.C., and Osang, T. (2007). Foreign Exchange Reserves and Import Demand: Evidence from Latin America. The World Economy, 30, 1477-89.

Arize, A.C., Malindretos, J., \& Grivoyannis, E.C. (2004). Foreign Exchange Reserves and Import Demand in Developing Economy: The Case of Pakistan. International Economic Journal, 18, 259-274.

Bera, A.K. and Mc Aleer, (1989). Nested and Non-Nested Method for testing linear and log-linear Regression Models. Sankhya B: The Indian Journal of Statistics, 51, 212-224.

Box, G.E.P., and Cox, D.R. (1964). An Analysis of Transformations. Journal of the Royal Statistical Society, series B 26, 211-252.

Boylan, T.A., Cuddy, M.P., and O'Muircheartaigh, I. (1980). The Functional Form of the Aggregate Import Demand Equation: A Comparison of Three European Economies. Journal of International Economics, 10, 561-566.

Carone, G. (1996). Modeling the U.S. Demand for Imports Through Cointegration and Error Correction. Journal of Policy Modeling, 18, 1-48.

Chang, T. Y.H. Ho and Juang, C.J. (2005). A Reexamination of South Korea's Aggregate Import Demand Function: The Bound Test Analysis. Journal of Economic Development, 30, 119-28.

Charemza, W.W., and Deadman, D.F. (1992). New Directions in Econometric Practice. England: Edward Elgar Publishing Ltd.

Cheong, T.T. (2003). Aggregate Impot Demand Function for Eighteen Countries: A Cointegration Analysis. IIUM Journal of Economics and Management, 11, 167-95.

Dash, A.K. (2005). An Econometric Estimation of the Aggregate Import Demand Function for India. IBRC Athen, Aryan Hellas Ltd. [Online] Available: www.aryanhellas.com/107/ad.pdf

Deyak, C.A., Sawyer, W.C., and Sprinkle, R.L. (1989). An Empirical Examination of the structural stability of the Disaggregated U.S. Import Demand. The Review of Economics and Statistics, 71, 337-341.

Dickey, D.A., and Fuller, W.A. (1979). Distribution of the Estimators for Autoregressive Time Series with Unit Root. Journal of the American Statistical Association, 74, 427-31.

Dickey, D.A., and Fuller, W.A. (1981). Likelihood Ratio Statistics for Autoregressive Time Series with Unit Root. Econometrica, 49, 1057-1072.

Dooodian, K., Koshal, R.K., and Al Muhanna, S. (1994). An Examination of Traditional Aggregate Import Demand Function for Saudi Arabia. Applied Economics, 26, 909-915.

Doroodian, K., Koshal, R.K., and Al-Muhanna, S. (1994). An Examination of Traditional Aggregate Import Demand Function for Saudi Arabia. Applied Economics, 26, 909-915.

Dutta, D., and Ahmad, N. (1997). An Aggregate Import Demand Function for Bangladesh: A Cointegration Approach. Applied Economics, 31, 465-472.

Dutta, D., and Ahmad, N. 2006. An Aggregate Import Demand Function for India: A Cointegration Analysis. [Online] Available: rspas.anu.edu.au/papers/asarc/dutta_ahmed_2.pdf

Engel, R.F., and Granger, C.W.J. (1987). Cointegration and Error Correction Model: Representation, Estimation and Testing. Econometrica, 55, 251-276. 
Gafar, John S. (1988). The Determinants of Import Demand in Trinidad and Tobago: 1967-84. Applied Economics, 55, 271-86.

Goldestein, M., and Khan, M.S. (1976). Large versus Small Price Changes and the Demand for Imports. IMF Staff Working Paper 3, 200-225.

Granger, C.W.J., and Newbold, P. (1974). Economic Forecasting: The Atheist Viewpoint. In: Modeling the Economy, G.A. Renton (Ed.), Heinemann, London.

Heien, Dale M. (1968). Structural Stability and the Estimation of International Import Price Elasticities in World Trade. Kyklos, 21, 695-711.

Houthakker, H.S., and Magee, S.P. (1969). Income and Price Elasticities in World Trade. Review of Economics and Statistics, 41, 111-25.

International Monetary Fund. (IMF). International Financial Statistics. Washington D.C., various issues.

International Monetary Fund (IMF). (2009). World Economic Outlook 2009. [Online] Available: www.imf.org/external/pubs/ft/weo/2009/01/.../index.aspx.

Johansen, S. (1988). Statistical Analysis of Cointegration Vectors. Journal of Economics Dynamics and Control, $12,231-54$.

Kalyoncu, H. (2006). An Aggregate Import Demand Function for Turkey. MPRA Paper No. 4260. [Online] Available: http://mpra.ub.uni-menchu.de/4260/.

Khan, M.S., and K.Z. Ross. (1977). The Functional Form of the Aggregate Import Demand Equation. Journal of International Economics, 7, 149-160.

Kmenta, J. (1986). Elements of Econometrics. 2nd edition, Macmillan, New York.

Kotan, Z and Saygili, M. (1999). Estimating an Import Function for Turkey. Discussion Paper No. 9909, The Central Bank of the Republic of Turkey. [Online] Available: www.tcmb.gov.tr/research/discus/dpaper40.pdf

Leamer, E.E., and Stern, R.M. (1970). Quantitative International Economics. Allyn and Bacon Inc., Boston.

Moran, C. (1989). Imports Under a Foreign Exchange Constraint. The World Bank Economic Review, 3, 279-95.

Murray, T., and Ginman, P.J. (1976). An Empirical Examination of Traditional Aggregate Demand Model. Review of Economics and Statistics, 58, 75-80.

Philips, P.C.B., and Perron, P. (1988). Testing for a Unit Root in Time Series Regression. Biometrica, 75, 335-46.

Salas, J. (1982). Estimation of the Structure and Elasticities of Mexican Imports in the Period 1961-1979.

Journal of Development Economics, 10, 297-311.

Sargan, J.D. (1964). Wages and Prices in the United Kingdom: A Study in Econometric Methodology. In P.E. Hart, G. Mills and J.K. Whitaker (Eds.), Econometric Analysis for National Economic Planning, Butterworth, London.

Sinha, D. (1997). Determinants of Import Demand in Thailand. International Economic Journal, 11, 73-83.

United Nations. (2009). UNCTAD Handbook of International Trade and Development Statistics. New York and Geneva. [Online] Available: www.unctad.org/templates/webflyer.asp?docid=10193...2068....

Urbain, J.P. (1992). Error Correction Model for Aggregate Imports: The Case of Two Small and Open Economies. In Dagenais, M.G. and P.A. Muet, (Eds.), International Trade Modelling, Chaoman and Hall, London, 237-278.

Table 1a. Result of Unit Root Test (Augmented Dicky-Fuller Test)

\begin{tabular}{|l|l|l|l|l|l|l|l|}
\hline \multirow{2}{*}{ Variables } & \multicolumn{4}{|l|}{ Level } & \multicolumn{4}{l|}{ First Difference } & Order of \\
\cline { 2 - 8 } & Constant & $\begin{array}{l}\text { Constant } \\
\text { and Trend }\end{array}$ & None & Constant & $\begin{array}{l}\text { Constant and } \\
\text { Trend }\end{array}$ & None & Integration \\
\hline LMt & 1.109382 & 0.162935 & 1.802921 & $-4.202355^{*}$ & $-4.374498^{*}$ & $-3.701294^{*}$ & I (1) \\
\hline LFEt & -0.292200 & -1.898862 & 1.583035 & $-4.625606^{*}$ & $-4.582328^{*}$ & $-4.478637^{*}$ & I (1) \\
\hline LGDPt & -2.034494 & -0.069380 & 0.308258 & $-4.058690^{*}$ & $-4.196733^{* *}$ & $-4.096426^{*}$ & I (1) \\
\hline LRPt & -0.707991 & -1.543094 & -1.368440 & $-4.303212^{*}$ & $-4.193323^{* *}$ & $-4.266150^{*}$ & I (1) \\
\hline Critical & & & & & & & \\
Values at & & & & & & & \\
$1 \%$, & -3.626784 & -4.219126 & -2.628961 & -3.621023 & -4.226815 & -2.628961 & \\
$5 \%$ & -2.945842 & -3.533083 & -1.950117 & -2.943427 & -3.536601 & -1.950117 & \\
$10 \%$ & -2.611531 & -3.198312 & -1.611339 & -2.610263 & -3.200320 & -1.611339 & \\
\hline
\end{tabular}

The critical values are those of McKinnon (1991). * *and** represents significant at $1 \%$ and $5 \%$ respectively. i.Lag lengths for the ADF test is chosen on the basis of the Schwarz Criteria (SIC). 
Table 1b. Result of Unit Root Test (Philips-Perron Test)

\begin{tabular}{|l|l|l|l|l|l|l|l|}
\hline \multirow{2}{*}{ Variables } & \multicolumn{2}{|l|}{ Level } & \multicolumn{3}{|l|}{ First Difference } & Order of \\
\cline { 2 - 8 } & Constant & $\begin{array}{l}\text { Constant } \\
\text { and Trend }\end{array}$ & None & Constant & $\begin{array}{l}\text { Constant } \\
\text { and Trend }\end{array}$ & None & Integration \\
\hline $\mathrm{Mt}$ & 0.583715 & -0.512908 & 2.119479 & -4.172383 & -4.374498 & -3.632257 & $\mathrm{I}(1)$ \\
\hline FEt & -0.281617 & -2.043407 & 2.028812 & -4.312663 & -4.175238 & -4.376534 & $\mathrm{I}(1)$ \\
\hline GDPt & -1.309478 & -0.857930 & 0.372626 & -3.989489 & -4.135697 & -4.028825 & I (1) \\
\hline RPt & -0.764756 & -1.543094 & -1.368440 & -4.201245 & -4.146373 & -4.226255 & I (1) \\
\hline Critical & & & & & & & \\
Values at & & & & & & & \\
$1 \%$, & -3.615588 & -4.219126 & -2.627238 & -3.621023 & -4.226815 & -2.628961 & \\
$5 \%$ & -2.941145 & -3.533083 & -1.949856 & -2.943427 & -3.536601 & -1.950117 & \\
$10 \%$ & -2.609066 & -3.198312 & -1.611469 & -2.610263 & -3.200320 & -1.611339 & \\
\hline
\end{tabular}

The critical values are those of McKinnon (1991).

$*$ and $* *$ represents significant at $1 \%$ and $5 \%$ level.

i. .Number of truncation lags in the PP Unit root test determined by the Newey -West criterion.

Table 2. Lag Order Selection Criteria

\begin{tabular}{|l|l|l|l|l|l|l|}
\hline Lag & LogL & LR & FPE & AIC & SC & HQ \\
\hline 0 & -41.67171 & NA & 0.000149 & 2.537317 & 2.713264 & 2.598727 \\
\hline 1 & 118.4549 & 275.7735 & $4.99 \mathrm{e}-08$ & -5.469715 & $-4.589982^{*}$ & -5.162664 \\
\hline 2 & 139.7420 & $31.93078^{*}$ & $3.85 \mathrm{e}-08^{*}$ & $-5.763447^{*}$ & -4.179928 & $-5.210756^{*}$ \\
\hline 3 & 147.1243 & 9.432919 & $6.83 \mathrm{e}-08$ & -5.284685 & -2.997380 & -4.486354 \\
\hline
\end{tabular}

* indicates lag order selected by the criterion

LR is sequential modified LR statistics

FPE denotes Final prediction error

AIC refers to Akaike Information criterion

$\mathrm{SC}$ is Schwarz information criterion

HQ denotes Hannan-Quinn information criterion

Table 3a. Result of Johansen's Cointegration Test

Lags interval (in first differences): 1 to 2

Unrestricted Cointegration Rank Test (Trace)

\begin{tabular}{|l|l|l|l|c|}
\hline Hypothesized No. of CE(s) & Eigen Value & Trace Statistics & 0.05 Critical Value & Prob.** \\
\hline None $*$ & 0.625792 & 59.38409 & 54.07904 & 0.0156 \\
\hline At most 1 & 0.282696 & 23.99815 & 35.19275 & 0.4629 \\
\hline At most 2 & 0.233721 & 12.03696 & 20.26184 & 0.4455 \\
\hline At most 3 & 0.065881 & 2.453440 & 9.164546 & 0.6868 \\
\hline
\end{tabular}

Trace test indicates 1 co-integrating eqn(s) at the 0.05 level

*denotes rejection of the hypothesis at 0.05 the level

**MacKinnon-Haug-Michelis(1999) p-values

Table 3b. Unrestricted Cointegration Rank Test (Maximum Eigen value)

\begin{tabular}{|l|l|l|l|l|}
\hline Hypothesized No. of CE(s) & Eigen Value & Max-Eigen Statistic & 0.05 Critical Value & Prob.** \\
\hline None* & 0.625792 & 35.38594 & 28.58808 & 0.0058 \\
\hline At most 1 & 0.282696 & 11.96119 & 22.29962 & 0.6586 \\
\hline At Most 2 & 0.233721 & 9.583515 & 15.89210 & 0.3738 \\
\hline At Most 3 & 0.065881 & 2.453440 & 9.164546 & 0.6868 \\
\hline
\end{tabular}

Max-eigen test indicates 1 co-integrating eqn(s) at the 0.05 level

*denotes rejection of the hypothesis at 0.05 the level

**MacKinnon-Haug-Michelis(1999) p-values 
Table 4. Estimate of Long Run Co-integrating Vector

Normalized Coefficients

\begin{tabular}{|l|l|l|l|l|}
\hline LM & LRP & LGDP & LFE & C \\
\hline 1.000000 & 0.289207 & -1.883348 & -0.209855 & 14.48683 \\
& $(0.13985)$ & $(0.27419)$ & $(0.06982)$ & $(3.00019)$ \\
\hline
\end{tabular}

The figures in small parentheses indicate standard error of the coefficients.

Table 5. Result of Error Correction Model

\begin{tabular}{|l|l|l|l|}
\hline Variables & Coefficients & Standard Error & t-values \\
\hline ECt-1 & -0.403959 & 0.06884 & -5.86774 \\
\hline$\Delta$ LMt-1 & 0.382506 & 0.10448 & 3.66108 \\
\hline$\Delta$ LMt-2 & 0.261186 & 0.10681 & 2.44527 \\
\hline$\Delta$ LRPt-1 & -0.194641 & 0.09947 & -1.95674 \\
\hline$\Delta$ LRPt-2 & 0.098909 & 0.10421 & 0.94909 \\
\hline$\Delta$ GDPt-1 & 0.613641 & 0.20101 & 3.05275 \\
\hline$\Delta$ GDPt-2 & 0.303400 & 0.21655 & 1.40106 \\
\hline$\Delta$ FEt-1 & 0.193349 & 0.03647 & 5.30176 \\
\hline$\Delta$ FEt-2 & 0.068717 & 0.04526 & 1.51816 \\
\hline $\begin{array}{l}\text { AR-square }=0.779803 \\
\text { LM }(1)=(0.7499), \mathrm{LM}(2)=(0.4256), \operatorname{LM}(3)=(0.4175),\end{array}$ \\
$\begin{array}{l}\text { Hetroskedasticity }=(0.5598) \\
\text { JB test }=(0.3012)\end{array}$
\end{tabular}

*indicates significant at 5 percent.

Figure in bracket shows significance level.

Table 6. VEC Granger Causality/ Block Exogeneity Wald Test

Dependent Variable $(\Delta \mathrm{LM})$

\begin{tabular}{|l|l|l|l|}
\hline Excluded & Chi-sq & Df & Prob. \\
\hline$\Delta$ LRP & 5.876405 & 2 & 0.0530 \\
\hline$\Delta$ GDP & 10.72014 & 2 & 0.0047 \\
\hline$\Delta$ FE & 45.93617 & 2 & 0.0000 \\
\hline All & 54.68288 & 6 & 0.0000 \\
\hline
\end{tabular}

Table 7. Composition of Imports (Percentage Share)

\begin{tabular}{|l|l|l|l|l|l|}
\hline Commodities & $1970-71$ & $1980-81$ & $1990-91$ & $2000-01$ & $2008-09$ \\
\hline I. Raw Materials and Intermediate Goods & 54.39 & 77.77 & 70.86 & 52.37 & 57.55 \\
\hline II. Capital goods* & 24.70 & 15.22 & 29.14 & 10.95 & 15.50 \\
\hline I + II & 79.1 & 92.99 & 90.00 & 63.32 & 73.15 \\
\hline IV.Total Imports & 100 & 100 & 100 & 100 & 100 \\
\hline
\end{tabular}

*From the year 1987-88 onwards, Capital Goods include Project Goods.

Source: Government of India, Economic Survey, 2009-10, page A-82 to A-84. 